\title{
Iron metabolism in the veal calf
}

\section{2.* Iron requirements and the effect of copper supplementation}

\author{
BY I. BREMNER AND A. C. DALGARNO \\ Rowett Research Institute, Bucksburn, Aberdeen $A B 29 S B$
}

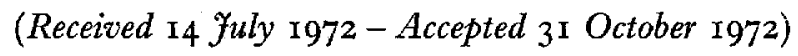

\begin{abstract}
I. The iron requirements of eighteen Ayrshire bull calves reared on fat-supplemented skim milk for I4 weeks from $c$. I $6 \mathrm{~d}$ of age have been studied. There was a highly significant relationship between dietary Fe intake (Io, 40 and $100 \mathrm{mg} / \mathrm{kg}$ dry diet) and blood haemoglobin concentration, packed cell volume and plasma $\mathrm{Fe}$ concentration.

2. A microcytic normochromic anaemia developed in the calves given a diet containing Io $\mathrm{mg} \mathrm{Fe} / \mathrm{kg}$ diet, but not in the other calves.

3. Plasma $\mathrm{Fe}$ concentrations increased to $>5 \mu \mathrm{g} \mathrm{Fe} / \mathrm{ml}$ in calves receiving $100 \mathrm{mg} \mathrm{Fe} / \mathrm{kg}$ diet but there were no effects of $F$ e treatment on plasma Fe-binding capacity, which rose from 4.9 to $8.4 \mu \mathrm{g} \mathrm{Fe} / \mathrm{ml}$ during the experiment. Saturation of plasma transferrin was only $3 \%$ in the Fe-deficient calves.

4. There were some significant effects of Fe treatment on tissue concentrations of $\mathrm{Fe}$ and cytochrome $c$.

5. Dietary supplementation with $5 \mathrm{mg}$ copper/kg dry diet had little effect on the growth or haematological status of the calves, although there were significant $\mathrm{Cu} \times \mathrm{Fe}$ interactions for mean corpuscular haemoglobin and mean corpuscular volume. There was no evidence of $\mathrm{Cu}$ deficiency in the calves, as measured by blood and liver $\mathrm{Cu}$ concentrations and by ceruloplasmin and cytochrome oxidase activities.
\end{abstract}

In a previous paper (Bremner \& Dalgarno, 1973) the haematological status of veal calves maintained on fat-supplemented skim milk was described. The effects of dietary supplementation with various forms of iron were investigated and differences in $\mathrm{Fe}$ availability were found. As the calves were found to be marginally copperdeficient the effects of dietary $\mathrm{Cu}$ supplementation were briefly studied. The present experiment was designed to assess more fully the $\mathrm{Fe}$ and $\mathrm{Cu}$ requirements of veal calves for the maintenance of normal blood indices.

\section{EXPERIMENTAL}

\section{Diets and supplements}

The diet, which consisted of a spray-dried emulsion of skim milk and fat, reconstituted with deionized water at $37^{\circ}$, has been described earlier (Bremner \& Dalgarno, I973). The $\mathrm{Fe}$ and $\mathrm{Cu}$ contents of the ration were 10.8 and $0.47 \mathrm{mg} / \mathrm{kg}$ milk powder respectively. The concentration of solids in the reconstituted milk was increased by about $\mathrm{I} 2 \mathrm{~g} / 1$ at weekly intervals over the first 5 weeks from I 8 to ${ }_{6} 6_{5} \mathrm{~g} / 1$ and was maintained thereafter at $\mathrm{r} 77 \mathrm{~g} / 1$. The calves were fed twice a day, from plastic buckets. The volume of milk given per feed was increased at weekly intervals by about 0.61 , from $2 \cdot 4$ to $8 \cdot 41$ over the first 12 weeks and was maintained at this level thereafter.

* Paper no. I: Br. J. Nutr. (1973) 29, 229. 
The $\mathrm{Fe}$ and $\mathrm{Cu}$ supplements were added to the milk in the form of aqueous solutions of $\mathrm{FeSO}_{4}$ and $\mathrm{CuSO}_{4}$ in the appropriate amounts.

\section{Experimental design}

The experiment was of a randomized block design and consisted of six treatments in each of three blocks of Ayrshire bull calves. The treatments, arranged in $3 \times 2$ factorial design, were:

\begin{tabular}{crc} 
& \multicolumn{2}{c}{$\begin{array}{c}\text { Supplement } \\
\text { (mg/kg dry feed) }\end{array}$} \\
Treatment & $\overbrace{\mathrm{Fe}}^{\mathrm{Cu}}$ \\
I & 0 & 0 \\
2 & 30 & 0 \\
3 & 90 & 0 \\
4 & 0 & 5 \\
5 & 30 & 5 \\
6 & 90 & 5
\end{tabular}

The calves were transferred to respiration chambers for $3 \mathrm{~d}$ in the course of the experiment, generally at some time during weeks 9-12, for determinations of basal metabolic rates (the results from this study will be reported in a separate publication). They were starved during this time and their food intake was restricted for a short time afterwards. All surviving calves were slaughtered after they had been on experiment for 14 weeks.

\section{Calves}

Details of the calves, which were on average $16 \mathrm{~d}$ old at the start of the experiment, and their care were as described previously (Bremner \& Dalgarno, 1973). During the experiment three calves died of ruminal or abomasal bloat (in treatment groups 2, 3 and 4) and one of heart failure (treatment I). In a fifth calf which died, there was dystrophic degeneration of muscle together with extensive pinpoint haemorrhage of the abomasal mucosa (treatment $\mathrm{r}$ ). One calf died after 8 weeks on experiment (treatment 2) and the tissues from this animal were not used for any analyses. Tissues from the other calves, which died during weeks Io-I 3 , were used for all analyses except total $\mathrm{Fe}$ as, with this one exception, the results did not reveal any consistent differences from those for the calves slaughtered normally.

\section{Analytical methods}

Plasma $\mathrm{Fe}$ and total Fe-binding capacity (TIBC) measurements were made by the automated method of Young \& Hicks (1965). Fe concentrations in freeze-dried tissues were determined on acid digests by the same method. Total non-haem Fe, ferritin and haemosiderin in liver and spleen were measured by the non-chromatographic methods of Drysdale \& Ramsay (1965). Cytochrome $c$ was measured by the method of Rosenthal \& Drabkin (1943).

Blood and tissue $\mathrm{Cu}$ concentrations were determined by atomic absorption spectroscopy. Plasma ceruloplasmin was measured by the method of Houchin (1958), using 
the standardization method of Rice (I962). Cytochrome oxidase activity was measured by the method of Mills \& Dalgarno (1970).

Statistical analysis of results was by standard analysis of variance techniques. Both mean untransformed and $\log$ values have been listed in the tables when there was evidence of heterogeneous variability. Only the latter have been used for significance tests.

\section{RESULTS}

Live-weight gain and food conversion ratio. The effects of dietary supplementation with $\mathrm{Fe}$ and $\mathrm{Cu}$ on live-weight gain and food conversion ratio are shown in Table I. Although no significant differences were detected between the various treatments, there was a trend for weight gains to increase with dietary $\mathrm{Fe}$ intake. Dietary $\mathrm{Cu}$ supplementation tended to decrease weight gains from an average of $\mathrm{x} \cdot \mathrm{O} 4$ to $0.93 \mathrm{~kg} / \mathrm{d}$.

Haematological measurements. The mean values of some of the blood indices at intervals during the experiment are given in Table 2 . No values have been given for calves after 12 weeks on experiment because the number of surviving calves was insufficient to permit statistical analysis. There was no consistent evidence that the addition of the $\mathrm{Cu}$ supplement in treatments $4^{-6}$ influenced these indices and the results have been quoted solely on the basis of $\mathrm{Fe}$ intake. Relationships between $\mathrm{Fe}$ intake and both haemoglobin concentration and packed cell volumes were noted after 5 weeks $(P<0.05)$. These persisted throughout the remainder of the experiment and their significance was greatest $(P<0.00 \mathrm{I})$ during weeks $9-\mathbf{I}$.

One calf receiving roo $\mathrm{mg}$ total $\mathrm{Fe} / \mathrm{kg}$ diet and no supplementary $\mathrm{Cu}$ behaved abnormally throughout the experiment. It was apparently incapable of utilizing much of the dietary $\mathrm{Fe}$ as its blood haemoglobin concentrations fell as low as $73 \mathrm{~g} / \mathrm{l}$. There were other effects also. Post-mortem examination revealed that this animal, which died of bloat, had extensive disease of the coronary arteries; this will be discussed later. Results for this animal have not been included in any of the statistical analyses.

In the later stages of the experiment the haemoglobin concentrations and packed cell volumes were significantly lower when the calves received a total of io $\mathrm{mg} \mathrm{Fe} / \mathrm{kg}$ diet than when $40 \mathrm{mg} \mathrm{Fe} / \mathrm{kg}$ diet were given, whereas increasing the Fe intake from 40 to $100 \mathrm{mg} / \mathrm{kg}$ diet did not cause such marked differences (Fig. I). The changes in haemoglobin concentrations and packed cell volumes were greatest in the early stages of the experiment. Calves receiving $40 \mathrm{mg} \mathrm{Fe} / \mathrm{kg}$ diet had their lowest haemoglobin concentrations after 7 weeks $(97 \mathrm{~g} / 1)$, whereas in the calves receiving $100 \mathrm{mg} \mathrm{Fe} / \mathrm{kg}$ diet there was a transient increase at week 6 followed by a gradual fall to around I $\mathrm{I} / \mathrm{g} / \mathrm{l}$. The average daily falls in haemoglobin concentrations over the 12 -week period were $0.745,0.2 \times 7$ and $0.275 \mathrm{~g} / 1$ (approximate $\mathrm{SE}$ of differences between means $=0.25 \mathrm{I}$ ) for calves receiving $\mathrm{I} 0,40$ and $100 \mathrm{mg} \mathrm{Fe} / \mathrm{kg}$ diet respectively.

There were no significant effects of treatment on either red cell or white cell counts, although there was a downward trend in the former over the experimental period. Plasma Fe concentrations were dependent on $\mathrm{Fe}$ but not on $\mathrm{Cu}$ intake (Table 2). Within 4 weeks a relationship between dietary $\mathrm{Fe}$ concentration and plasma $\mathrm{Fe}$ 

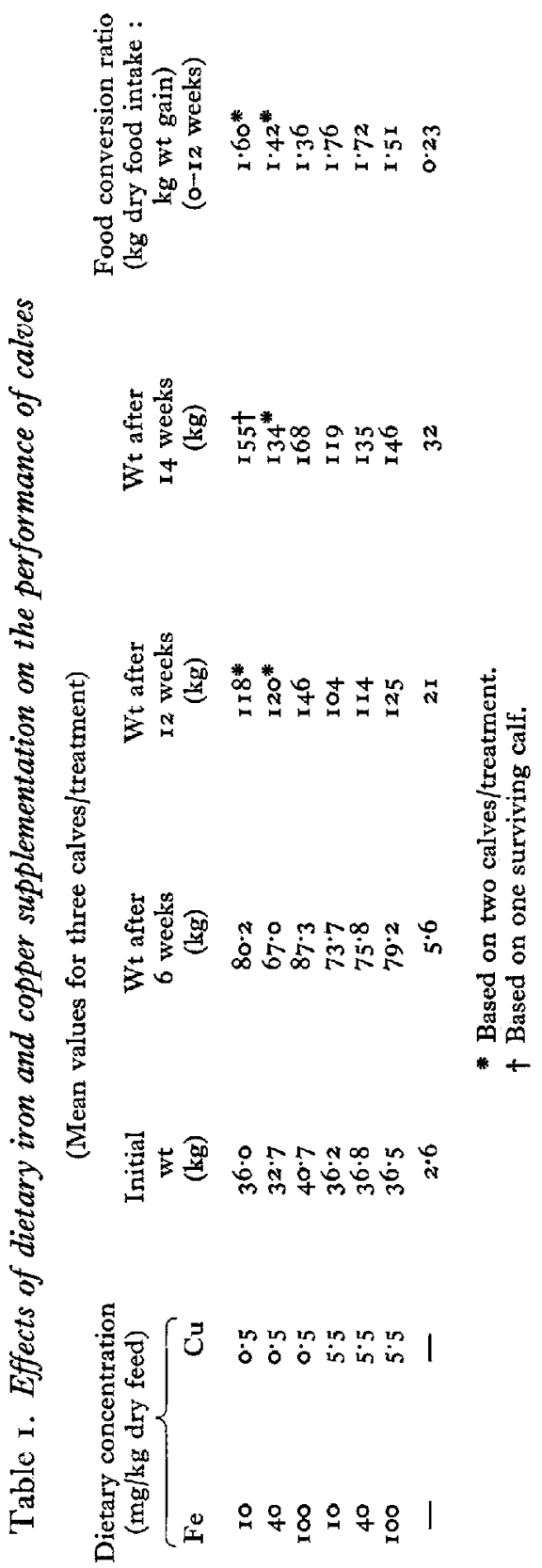

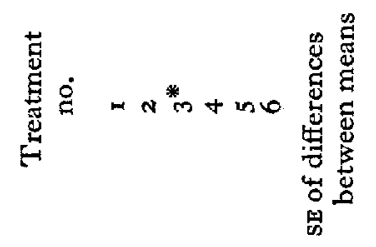


Vol. 30

Iron and copper supplements for veal calves

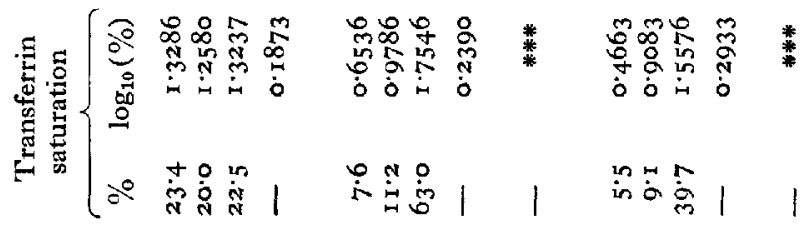

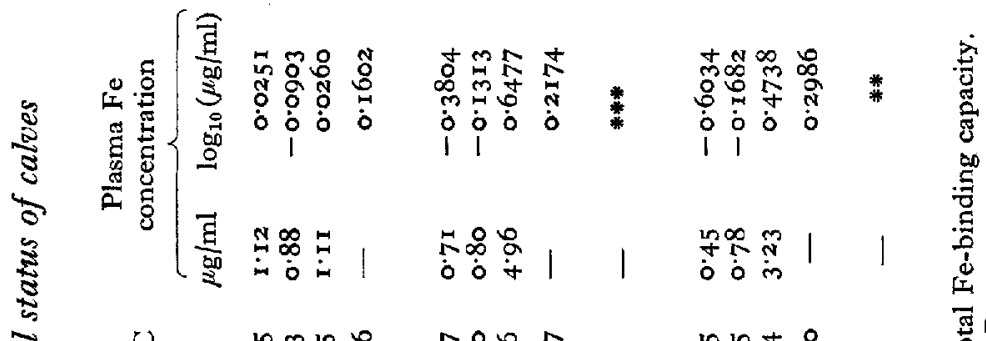

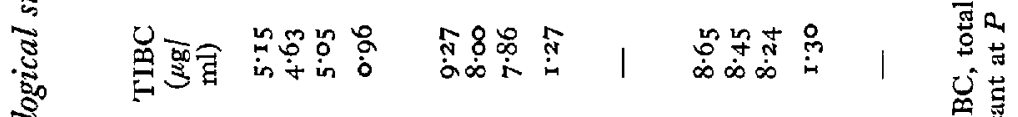

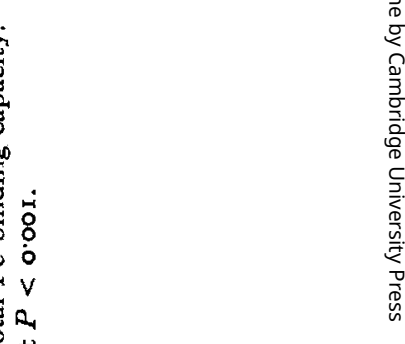

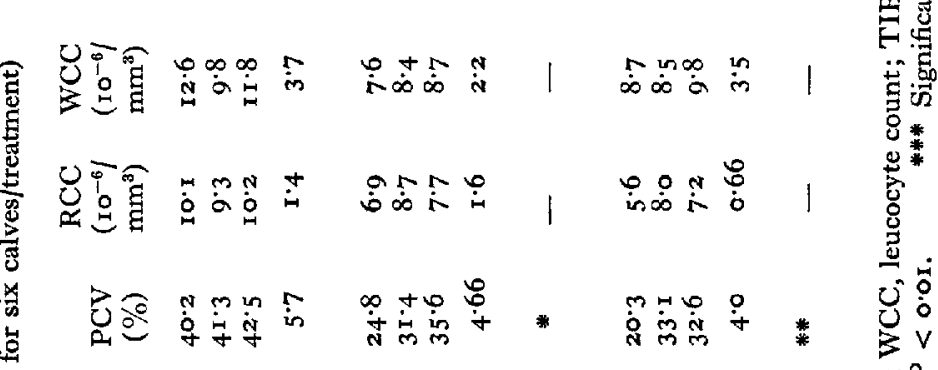

苨萖

हैं

i

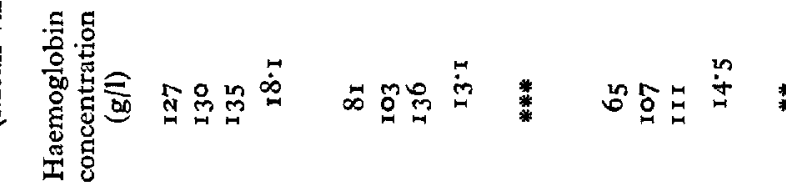

$\frac{1}{8}$

至

5

芯

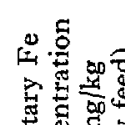

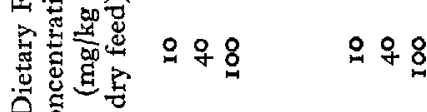

O +8 1 I

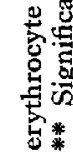

$\frac{0}{0}$

A

尊苞营

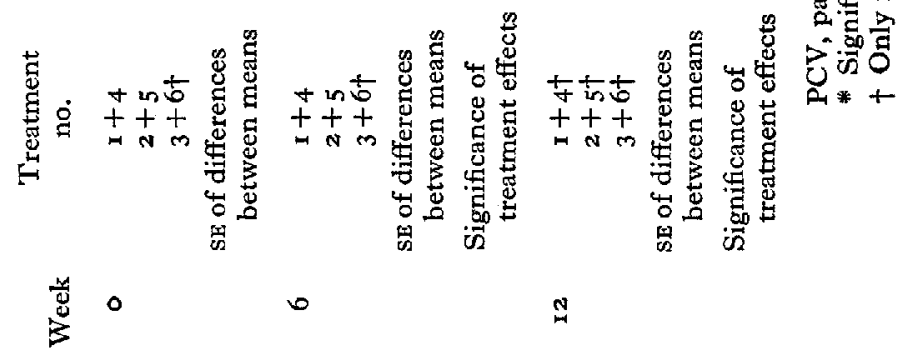




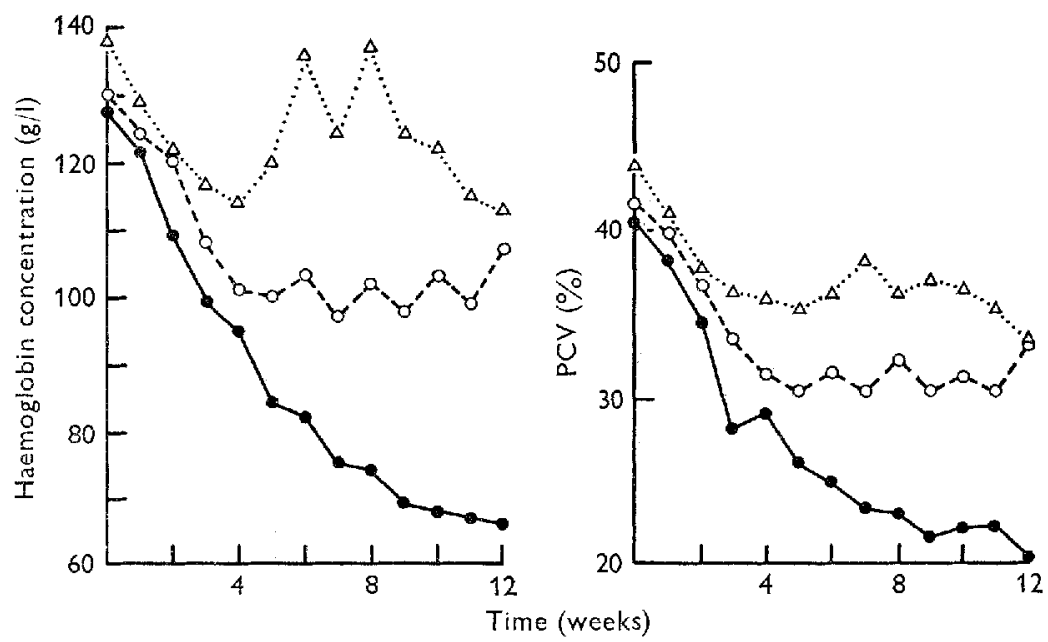

Fig. I. Effect of iron treatment on haemoglobin concentration and packed cell volume (PCV) in calves receiving diets containing $10(O), 4^{\circ}(O)$ and $100(\Delta) \mathrm{mg} \mathrm{Fe} / \mathrm{kg}$.

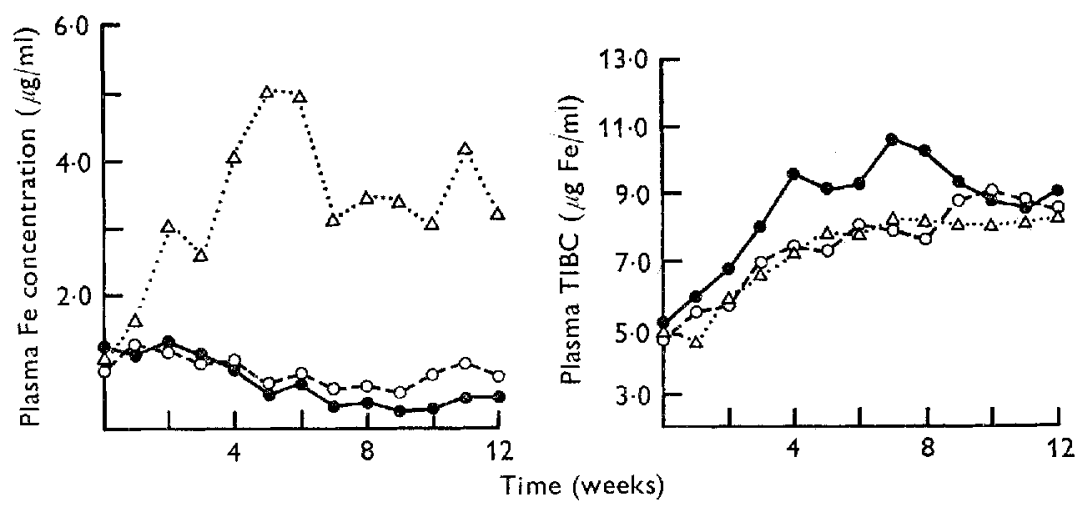

Fig. 2. Effect of iron treatment on plasma Fe concentration and total Fe-binding capacity (TIBC) in calves receiving diets containing $\mathrm{IO}(\mathrm{O}), 40(\mathrm{O})$ and $\mathrm{IOO}(\Delta) \mathrm{mg} \mathrm{Fe} / \mathrm{kg}$.

concentration was evident $(P<0.05)$. This persisted throughout, but was most significant $(P<0.01$ and $<0.001)$ in the middle of the experiment. From Fig. 2 it can be seen that, after a small increase over the ist week, there was a downward trend in plasma Fe concentrations for calves receiving Io or $40 \mathrm{mg} \mathrm{Fe} / \mathrm{kg}$ diet, with a tendency for plasma Fe concentrations to increase in later weeks when $40 \mathrm{mg} \mathrm{Fe} / \mathrm{kg}$ diet were given. Plasma Fe concentrations for calves given $100 \mathrm{mg} \mathrm{Fe} / \mathrm{kg}$ diet rose over the first 5 weeks to $>5 \mu \mathrm{g} / \mathrm{ml}$ (for some individual calves concentrations $>6 \mu \mathrm{g} / \mathrm{ml}$ were recorded) but fell later to around $3.0 \mu \mathrm{g} \mathrm{Fe} / \mathrm{ml}$. It is of interest to compare these plasma $\mathrm{Fe}$ concentrations with those for the calf receiving $100 \mathrm{mg} \mathrm{Fe} / \mathrm{kg}$ diet, which had disease of the coronary arteries. Initially the plasma Fe concentrations were high in this calf $(2.5 \mu \mathrm{g} / \mathrm{ml})$ but they fell rapidly and from week 6 onwards were about 0.25 $\mu \mathrm{g} \mathrm{Fe} / \mathrm{ml}$, that is, about $8 \%$ of the concentration in other calves with the same $\mathrm{Fe}$ intake. 
TIBC in the plasma increased from about $5 \mu \mathrm{g} \mathrm{Fe} / \mathrm{ml}$ at the start of the experiment to about $9 \mu \mathrm{g} \mathrm{Fe} / \mathrm{ml}$ from week 6 onwards (Table 2 and Fig. 2). There was no effect of $\mathrm{Cu}$ supplementation and (with the exception of week $4, P<0.05$ ) no statistically significant effect of $\mathrm{Fe}$ on TIBC, although there was a trend towards a higher TIBC in calves receiving $10 \mathrm{mg} \mathrm{Fe} / \mathrm{kg}$ diet. The degree of saturation of the plasma transferrin was highly significantly dependent on $\mathrm{Fe}$ intake (Table 2 ). In calves receiving to and $40 \mathrm{mg} \mathrm{Fe} / \mathrm{kg}$ diet there was a gradual decrease from $22 \%$ saturation to 3 and $6 \%$ respectively after 9 weeks. In calves receiving $100 \mathrm{mg} \mathrm{Fe} / \mathrm{kg}$ diet, the degree of saturation increased initially to $65 \%$ (week 5 ) and then decreased to about $40 \%$ in subsequent weeks.

Calculation of mean cell volumes (MCV), mean corpuscular haemoglobin (MCH) and mean corpuscular haemoglobin concentrations (MCHC) revealed considerable week-to-week variations. However, when the average values of these measurements over the 9-12 week period were compared, linear relationships between $\mathrm{Fe}$ intake and $\operatorname{MCV}(P<0.001), \operatorname{MCH}(P<0.001)$ and MCHC $(P<0.01)$ wcre found with, in addition, $\mathrm{Cu} \times \mathrm{Fe}$ interactions for $\mathrm{MCV}(P<0.05)$ and $\mathrm{MCH}(P<0.05)$ (Table 3$)$. The anaemia of the unsupplemented calves was microcytic, especially for the calves given supplementary $\mathrm{Cu}$ but, conversely, mean cell volumes were greatest when maximum supplements of $\mathrm{Fe}$ and $\mathrm{Cu}$ were given. Although the hypochromicity of the cells was increased with low Fe intake, the MCHC was not sufficiently low (3I2 g/l) for the anaemia to be classified as hypochromic.

There were no statistically significant effects of treatment on the weights and, with the exception of liver, dry-matter (DM) contents of tissues. The DM content of liver was greatest when the diet contained $40 \mathrm{mg} \mathrm{Fe} / \mathrm{kg}$ (Table 4 ). The trend in most tissues was for the Fe concentration to be related to the dietary Fe concentration but, as a result of the high mortality rate of the calves and the inclusion of results for slaughtered animals only, the statistical analysis is necessarily imprecise. In the calves given supplementary $\mathrm{Cu}$, tissue $\mathrm{Fe}$ concentrations about doubled when the dietary Fe intake was increased from Io to $100 \mathrm{mg} / \mathrm{kg}$ diet. There was some indication that $\mathrm{Fe}$ concentrations were also influenced by supplementary $\mathrm{Cu}$, especially in spleen, where it caused a $40-50 \%$ reduction.

About $30 \%$ of the total $\mathrm{Fe}$ in the livers was present in the form of non-haem $\mathrm{Fe}$, compared with about $12 \%$ in the spleen. Although no statistically significant effects were noted, there was a strong tendency for concentrations of non-haem $\mathrm{Fe}$ in the liver to be lower in calves given $\mathrm{Cu}$ (Table 5). There was a significant effect of dietary $\mathrm{Fe}$ on total non-haem $\mathrm{Fe}$, ferritin and haemosiderin in spleen, where about $24-38 \%$ of the non-haem $\mathrm{Fe}$ was present as ferritin, compared with $8-16 \%$ in liver. The remainder of the non-haem $\mathrm{Fe}$ was mainly haemosiderin, although the fact that the sum of ferritin and haemosiderin Fe frequently exceeded the estimated total non-haem Fe suggests that the separation procedures did not always differentiate clearly between these Fe compounds.

Blood $\mathrm{Cu}$ and ceruloplasmin concentrations were not affected by either $\mathrm{Fe}$ or $\mathrm{Cu}$ treatment (Table 6). There was a significant decrease in blood $\mathrm{Cu}$ concentration with all treatments over the experimental period, from a mean of $\mathrm{I} \cdot 28$ to $\mathrm{I} \cdot 05 \mu \mathrm{g} / \mathrm{ml}(\mathrm{sE}=$ 


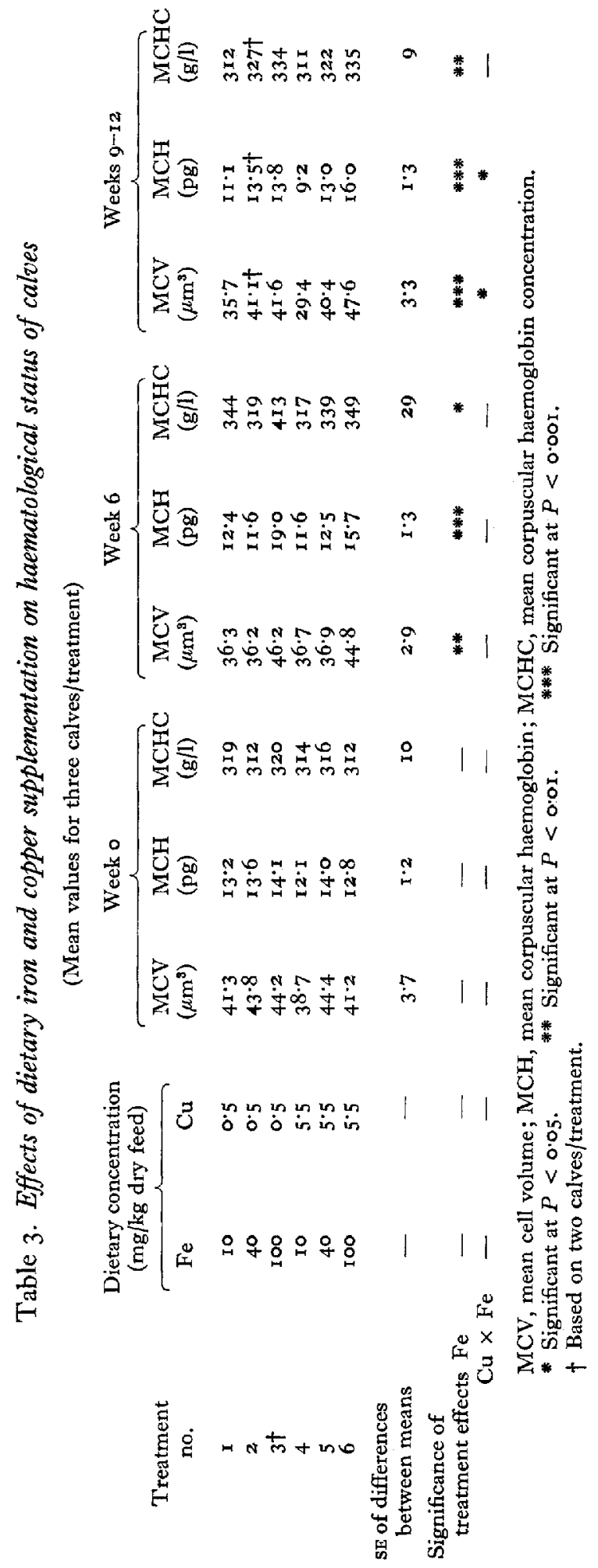


Vol. $3^{\circ}$

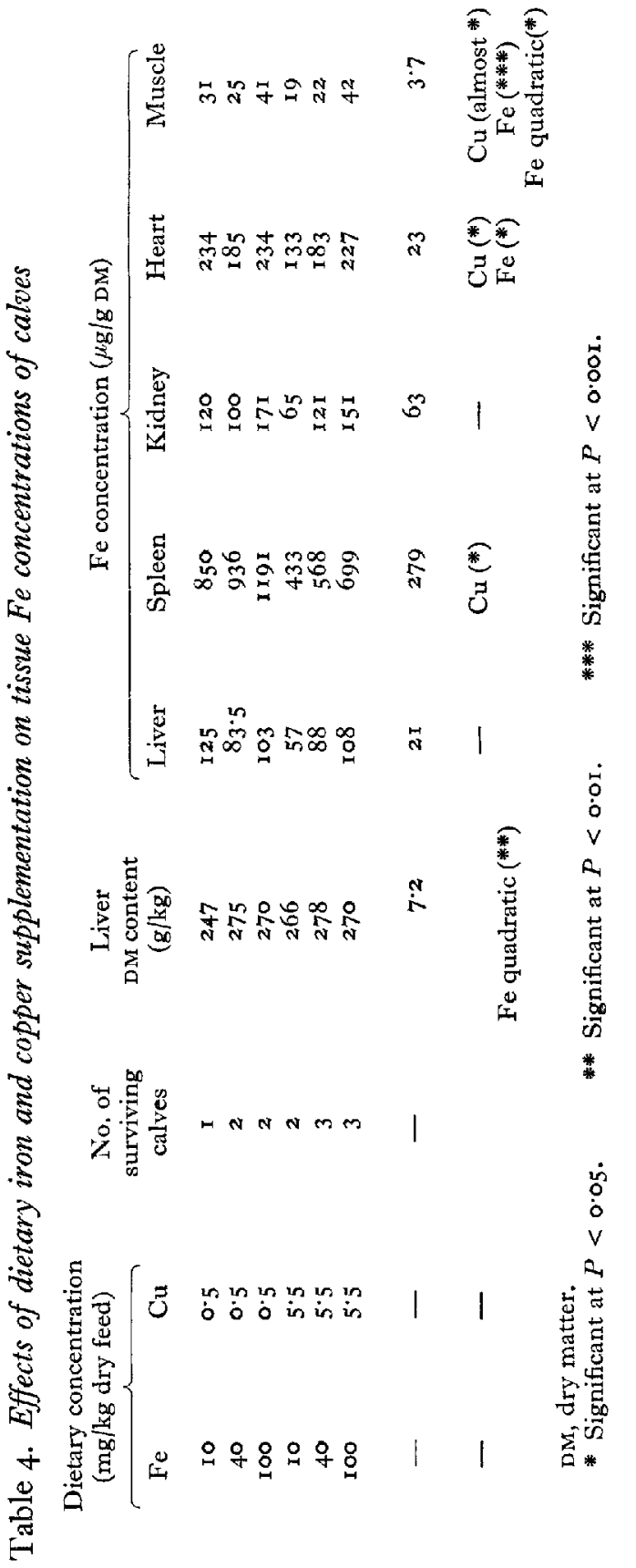

$$
\text { 焉 }
$$




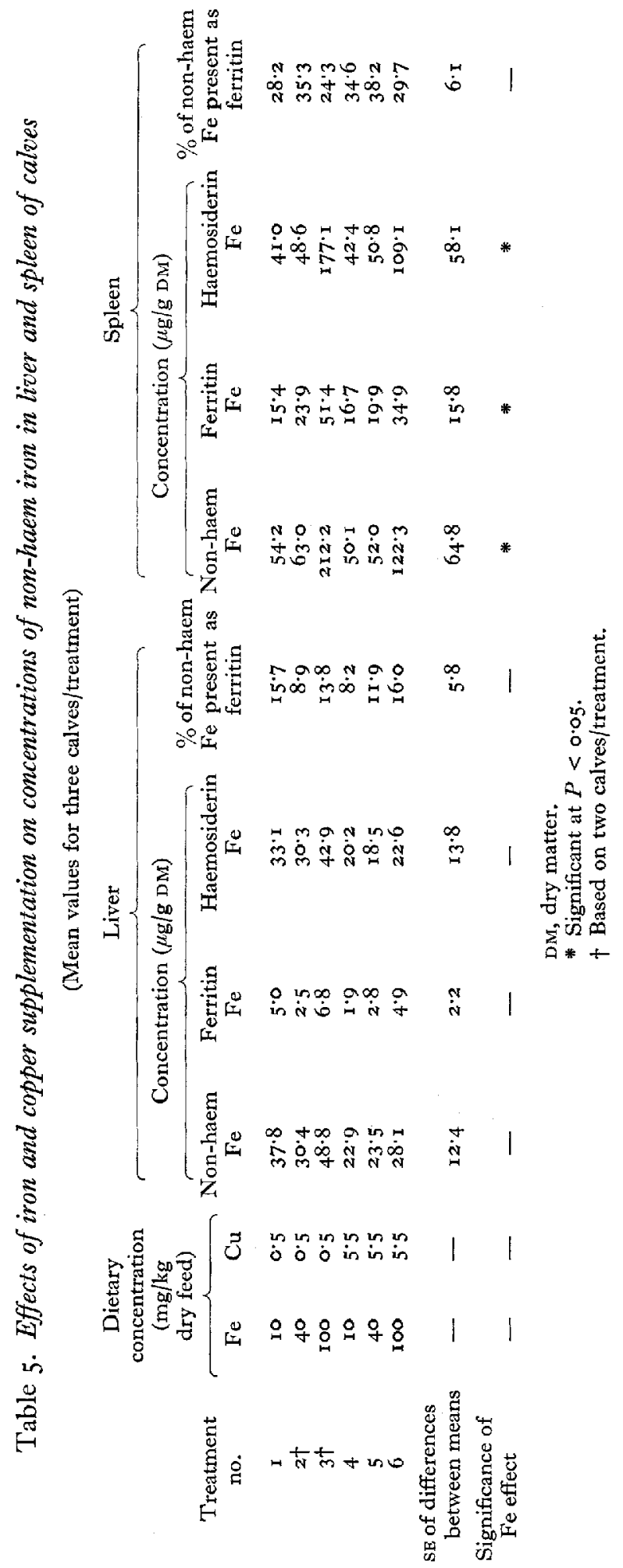


Vol. 30

Iron and copper supplements for veal calves

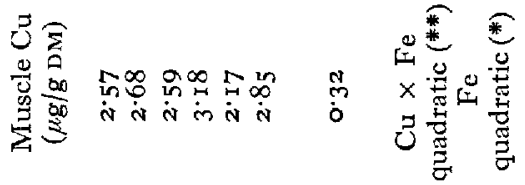

$\exists \overline{\mathrm{z}}$

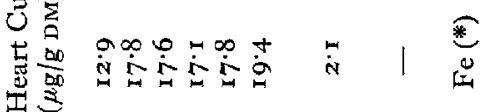

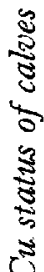

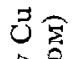

乐要

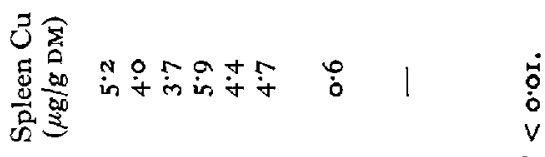

รี

兽

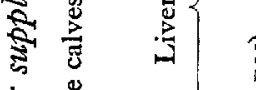

迹

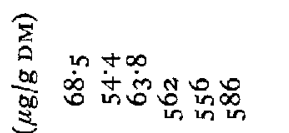

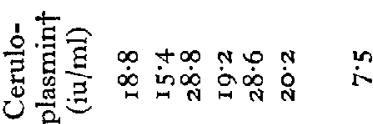

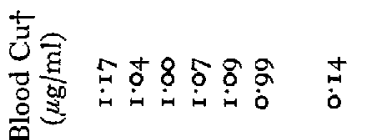

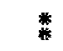

3.

: 


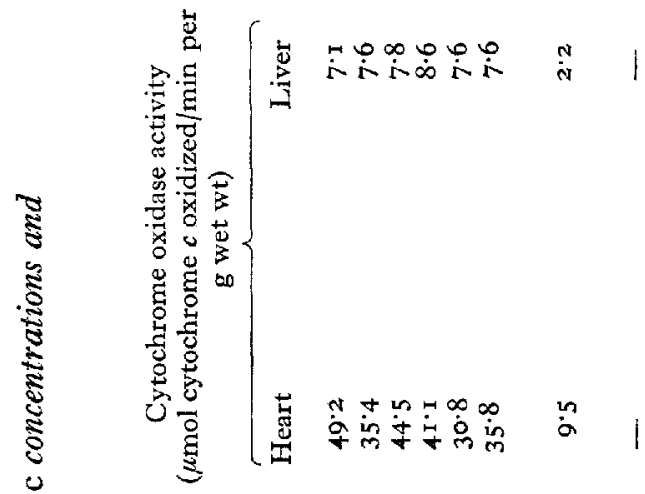

है

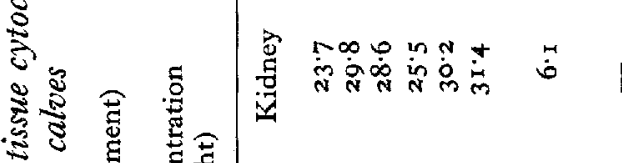
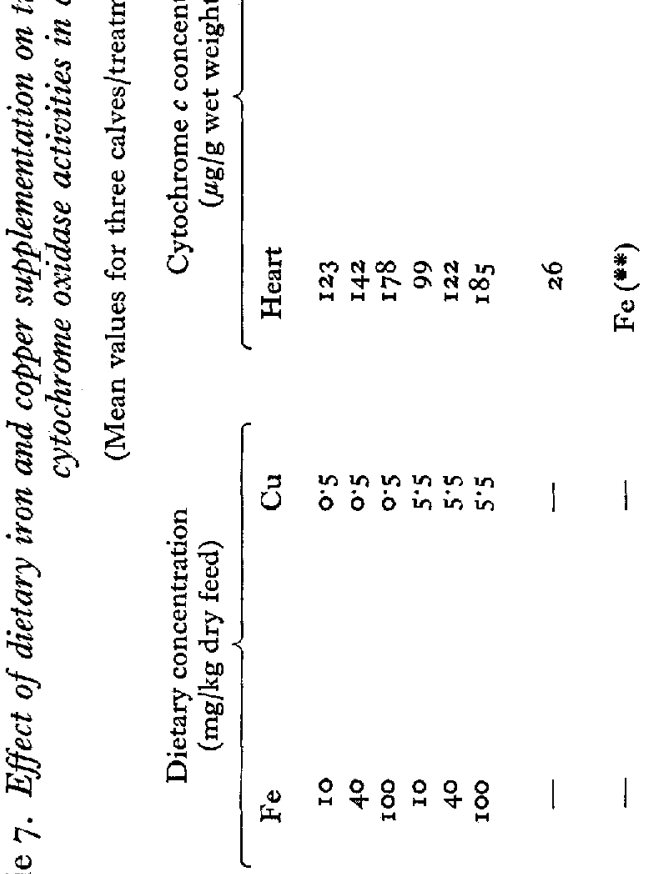

䓪

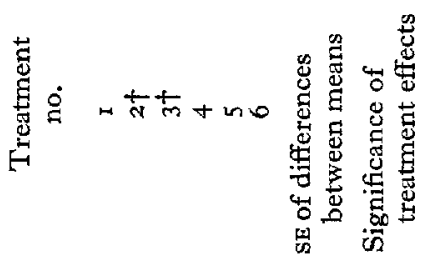


0.055 ). In only one instance was the blood $\mathrm{Cu}$ concentration $<0.8 \mu \mathrm{g} / \mathrm{ml}$. The main effect of the supplementary $\mathrm{Cu}$ was to increase liver $\mathrm{Cu}$ concentrations to $>550 \mu \mathrm{g} / \mathrm{g}$ $\mathrm{DM}$ (Table 6). These tended to be also dependent on $\mathrm{Fe}$ intake in calves given no $\mathrm{Cu}$ supplement, with lowest mean $\mathrm{Cu}$ concentrations occurring when the total dietary $\mathrm{Fe}$ concentration was $40 \mathrm{mg} / \mathrm{kg}$. There were no significant effects of dietary $\mathrm{Cu}$ on $\mathrm{Cu}$ concentrations in kidney, heart or spleen. In spleen the Cu concentration decreased as Fe intake increased $(P<0.05)$, whereas in heart they were directly related $(P<0.05)$.

The activity of cytochrome oxidase in both liver and heart was determined in order to obtain more information on the relative $\mathrm{Cu}$ status of the calves. There were no significant effects of either $\mathrm{Cu}$ or Fe treatment (Table 7). Concentrations of cytochrome $c$ in heart were significantly dependent on Fe intake $(P<0.01)$ but in kidney, although a similar trend was evident, the differences were not significant.

\section{DISCUSSION}

Eeckhout, Casteels \& Buysse ( I 969) have reported that the performance of veal calves is related to their dietary $\mathrm{Fe}$ intake. The failure to observe significant treatment effects in either this or the previous experiment (Bremner \& Dalgarno, I973) can perhaps be attributed to the large variations in the Fe status of individual calves at birth and the small number of animals in each replicate. However, there was a tendency for $\mathrm{Fe}$ supplementation to improve, and $\mathrm{Cu}$ supplementation to reduce, weight gain and food conversion ratio. The inferior performance of the calves in this, compared with the previous, experiment was partly a consequence of the starvation period involved in the determination of basal metabolic rate. Average daily weight gains over the first $\mathrm{I} 2$ weeks were I'OI kg/d compared with $\mathrm{I} \cdot \mathrm{I} 4 \mathrm{~kg} / \mathrm{d}$.

A dietary intake of $100 \mathrm{mg} \mathrm{Fe} / \mathrm{kg}$ was found to be insufficient to prevent a decrease in blood haemoglobin concentrations and in packed cell volumes during the experiment. The final haemoglobin concentrations were, however, similar to those reported for adult cattle (I I0-120 g/l; Underwood, I97I). There was little difference between the final haemoglobin concentrations attained when the dietary Fe concentration was 40 or $100 \mathrm{mg} / \mathrm{kg}$, although the initial decrease in haemoglobin concentration was greater with the diet containing $40 \mathrm{mg} / \mathrm{kg}$. At no time were the mean haemoglobin concentrations in these calves indicative of a state of anaemia. The calves receiving io $\mathrm{mg} \mathrm{Fe} / \mathrm{kg}$ diet became progressively more anaemic as the experiment continued, although the average rate of decrease in haemoglobin concentration $(0.74 \mathrm{~g} / \mathrm{l}$ per d) was less than that reported previously $(0.82 \mathrm{~g} / 1$ per $\mathrm{d}$ ) (Bremner \& Dalgarno, I973). In the calves given $40 \mathrm{mg} / \mathrm{kg}$ diet, the rates of decrease were 0.22 and $0.30 \mathrm{~g}$ haemoglobin $/ 1$ per $\mathrm{d}$ in this and the previous experiment respectively. It seems probable that these differences between the two experiments reflect the decreased growth rates and also the greater initial haemoglobin concentrations in the present experiment $(\mathrm{I} 3 \circ \mathrm{g} / \mathrm{l})$ compared with the previous one ( $108 \mathrm{~g} / 1)$.

The changes in packed cell volume were generally similar to those in haemoglobin concentration, and consequently there was little change in MCHC throughout the experiment. The occurrence of a relationship between MCV and dietary Fe intake 
agrees with the known microcytic character of Fe-deficiency anaemia in calves (Blaxter, Sharman \& MacDonald, I957). It is not clear how important is the somewhat inconsistent $\mathrm{Cu} \times \mathrm{Fe}$ interaction in which a low $\mathrm{Cu}$ intake resulted in the cell volumes being greater than normal when the $\mathrm{Fe}$ intake was low and smaller when Fe intake was high. This conflicts with the report that $\mathrm{Cu}$ deficiency in cattle causes a macrocytic anaemia (Cunningham, 1946).

The plasma $\mathrm{Fe}$ concentrations recorded when milk containing $100 \mathrm{mg} \mathrm{Fe} / \mathrm{kg}$ was given to the calves were remarkably high (being $>4 \mu \mathrm{g} / \mathrm{ml}$ at weeks $4^{-6}$ ) compared with the concentrations of around $\mathrm{I} \cdot 4 \mu \mathrm{g} / \mathrm{ml}$ reported in Australia for milk-fed calves of similar age which had access to dry feed with an Fe content of $300-450 \mathrm{mg} / \mathrm{kg}$ (K. C. Bremner, I966). These higher concentrations may reflect the greater availability of $\mathrm{Fe}$ when it is in soluble form, although that does not explain why they were not attained until some weeks after the start of the experiment. It is of interest that, unlike the situation normally encountered in Fe-deficiency anaemia, there was no effect of $\mathrm{Fe}$ supplementation on TIBC. The persistence of TIBC values from week 8 onwards of $>8 \mu \mathrm{g} \mathrm{Fe} / \mathrm{ml}$ again conflicts with the findings of $\mathrm{K}$. C. Bremner ( $\mathrm{ig66}$ ), who reported values of only $4 . \mathrm{I} \mu \mathrm{g} \mathrm{Fe} / \mathrm{ml}$ in 3 -month-old calves, although there was a transient increase to $6 \cdot 5-8 \cdot 4 \mu \mathrm{g} \mathrm{Fe} / \mathrm{ml}$ in the ist month after birth. It has been suggested that TIBC is regulated by tissue oxygen balance and is related to blood haemoglobin concentration (Morgan, 1962) but no such relationship was observed here.

The only tissues in which there was a significant dependence of Fe concentration on dietary Fe treatment were muscle, heart and (non-haem Fe only) spleen. Concentrations of $\mathrm{Fe}$ in most organs, and especially in spleen, were higher than those reported previously (Bremner \& Dalgarno, 1973). The concentrations of non-haem Fe in liver were similar to those recorded previously for veal calves (Charpentier, I966) but much less than those recorded by K. C. Bremner \& Ronalds (1965) for conventionally reared calves of similar age. Their suggestion that concentrations of non-haem $\mathrm{Fe}<$ $20 \mu \mathrm{g} / \mathrm{g}$ fresh liver (i.e. $<70-80 \mu \mathrm{g} / \mathrm{g} \mathrm{DM}$ ) are indicative of Fe deficiency is not supported by our results. It may be, however, that there are differences in Fe metabolism between milk-fed and conventionally reared calves. The distribution of non-haem $\mathrm{Fe}$ between ferritin and haemosiderin in liver and spleen was similar to that found in young rats before weaning (Leslie \& Kaldor, I971).

In addition to the development of anaemia, Fe deficiency has been shown to cause several, well-defined tissue changes in rats (Beutler, I964) and pigs (Gubler, Cartwright \& Wintrobe, I957) but not so far in calves. Dallman (I969) has demonstrated that the reduction in tissue concentrations of haem protein in rats is an early manifestation of Fe depletion, especially during the early period of rapid growth. It is of interest, therefore, that in this experiment cytochrome $c$ concentrations in heart were dependent on $\mathrm{Fe}$ intake, as were myoglobin concentrations in skeletal muscle (MacDougall, Bremner and Dalgarno, to be published). Furthermore, the differences in tissue concentrations of haem protein between animals receiving 40 and $100 \mathrm{mg}$ $\mathrm{Fe} / \mathrm{kg}$ diet were greater than the differences in final blood haemoglobin concentrations, although these differences in haemoglobin concentration were not so small in the earlier stages of the experiment. 
Dietary supplementation with $\mathrm{Cu}$ tended to reduce weight gains and had a significant effect on spleen Fe concentrations. The reduction in liver non-haem $\mathrm{Fe}$, although not statistically significant, was similar to a decrease of $34 \%$ reported in the previous experiment (Bremner \& Dalgarno, 1973) and attributed to an increase in ceruloplasmin and therefore ferroxidase activity. However, ceruloplasmin concentrations were unaffected by $\mathrm{Cu}$ treatment in this experiment and it must be presumed that the concentrations of $\mathrm{Fe}$ on $\mathrm{Cu}$ treatment were reduced by some other mechanism.

Liver $\mathrm{Cu}$ reserves in cattle diminish during the grazing season and are replenished when the cattle are on winter rations (Hartmans \& Bosman, 1970) and foetal $\mathrm{Cu}$ reserves in other ruminants are dependent on maternal $\mathrm{Cu}$ status (Suttle \& Field, 1968). The calves in the previous experiment were born in the autumn and might therefore have had smaller $\mathrm{Cu}$ reserves than those in this experiment which were born in the spring. It is noteworthy, therefore, that the Cu status of all but one of the calves in the present experiment was satisfactory, whereas in the previous experiment (Bremner \& Dalgarno, 1973) there was in many instances evidence of $\mathrm{Cu}$ deficiency. Liver $\mathrm{Cu}$ concentrations in calves given no supplementary $\mathrm{Cu}$ in this experiment averaged $60 \mu \mathrm{g} / \mathrm{g}$ DM, compared with $25 \mu \mathrm{g} / \mathrm{g}$ DM in the previous experiment. In neither experiment were blood $\mathrm{Cu}$ and ceruloplasmin concentrations or cytochrome oxidase activities abnormally low.

The high liver $\mathrm{Cu}$ concentrations ( $>55^{\circ} \mu \mathrm{g} / \mathrm{g}$ DM) in the supplemented calves again illustrate the extremely high affinity of that organ for $\mathrm{Cu}$ in young calves. Over $50 \%$ of the dietary $\mathrm{Cu}$ was retained in the liver, which is much greater than $\mathrm{Cu}$ retention reported in other species. C. F. Mills (personal communication) has recorded liver retention of between only 3 and $7 \%$ in lambs maintained on different rations. It may be that the high absorption of $\mathrm{Cu}$ is related to the milk-feeding of the calves.

Sourkes, Lloyd \& Birnbaum (1968) reported that there was an inverse relationship between dietary Fe intake and liver Cu concentration in rats, and Marston, Allen \& Swaby (1971) found the same relationship in heart when the diet contained adequate $\mathrm{Cu}$ although, in one experiment only, there was a direct relationship when the diet was $\mathrm{Cu}$-deficient. Different relationships between $\mathrm{Fe}$ intake and $\mathrm{Cu}$ concentrations were found in this experiment in liver ( $\mathrm{Cu} \times \mathrm{Fe}$ quadratic), heart (direct), spleen (inverse) and muscle $(\mathrm{Cu} \times \mathrm{Fe}$ quadratic). These cannot be explained at present but similar trends in spleen were observed previously for comparable dietary treatments.

A common sign of $\mathrm{Cu}$ deficiency in avian species is the occurrence of aortic rupture, which results from a failure of elastin formation associated with reduction in the activity of the Cu-enzyme amine oxidase (Bird, Savage \& O'Dell, 1966). It is of some interest, therefore, that the only calf which showed signs of $\mathrm{Cu}$ deficiency also showed signs of severe arteritis of larger coronary vessels of the heart, with thickening of endothelium and fragmentation of elastic membranes. There is no direct evidence, however, that these changes were connected with the animal's Cu-deficient state, and it may be relevant that there were disturbances of $\mathrm{Fe}$ metabolism also.

In conclusion, it has been confirmed that a microcytic normochromic anaemia develops in Ayrshire veal calves given no supplementary Fe. A diet containing $40 \mathrm{mg}$ 
$\mathrm{Fe} / \mathrm{kg}$ prevented the anaemia but did not eliminate the initial reduction in blood haemoglobin concentrations. An intake of $100 \mathrm{mg} / \mathrm{kg}$ diet had little further effect on the haematological status of the calves, especially when they were near to slaughter weight, although there were effects on plasma $\mathrm{Fe}$, heart cytochrome $c$ and muscle $\mathrm{Fe}$ concentrations. Although there was some $\mathrm{Cu} \times \mathrm{Fe}$ interaction, this did not seriously affect the haematological status of the calves. It seems that the $\mathrm{Fe}$ and $\mathrm{Cu}$ reserves of the calf at birth may be of some importance in determining its requirement for these elements when it is reared for veal production.

The authors are grateful to Mr J. Mathieson for the iron analyses, Mr G. A. M. Sharman for haematological analyses, Mr I. McDonald for statistical analysis and Mr R. B. Marshall for technical assistance.

\section{REFERENCES}

Beutler, E. (1964). In Iron Metabolism p. 256 [F. Gross, editor]. Berlin: Springer-Verlag. Bird, D. W., Savage, J. E. \& O'Dell, B. L. (1966). Proc. Soc. exp. Biol. Med. 123, 250. Blaxter, K. L., Sharman, G. A. M. \& MacDonald, A. M. (I957). Br. F. Nutr. r1, 234.

Bremner, I. \& Dalgarno, A. C. (1973). Br. F. Nutr. 29, 229.

Bremner, K. C. (1966). Aust. F. exp. Biol. med. Sci. 44, 259.

Bremner, K. C. \& Ronalds, J. A. (1965). Aust. F. exp. Biol. med. Sci. 43, 593.

Charpentier, J. (rg66). Annls Zootech. 15, 181.

Cunningham, I. J. (1946). N.Z. Il Sci. Technol. Sect. A, 27, 38 I.

Dallman, P. R. (r969). F. Nutr. 97, 475 .

Drysdale, J. W. \& Ramsay, W. N. M. (1965). Biochem. F. 95, 282.

Eeckhout, W., Casteels, M. \& Buysse, F. (1969). Annls Zootech. 18, 249.

Gubler, C. J., Cartwright, G. E. \& Wintrobe, M. M. (1957). F. biol. Chem. 224, 533.

Hartmans, J. \& Bosman, M. S. M. (1970). In Trace Element Metabolism in Animals p. 362 [C. F. Mills, editor]. Edinburgh: E. and S. Livingstone.

Houchin, O. B. (I958). Clin. Chem. 4, 5 I9.

Leslie, A. J. \& Kaldor, I. (I97I). Am. $¥$. Physiol. 220, 1000.

Marston, H. R., Allen, S. H. \& Swaby, S. L. (1971). Br. J. Nutr. 25, 15.

Mills, C. F. \& Dalgarno, A. C. (1970). In Trace Element Metabolism in Animals p. 456 [C. F. Mills, editor]. Edinburgh: E. and $\mathrm{S}$. Livingstone.

Morgan, E. H. (1962). Q. भl exp. Physiol. 47, 57.

Rice, E. W. (1962). Analyt. Biochem. 3, 452 .

Rosenthal, O. \& Drabkin, D. L. (1943). F. biol. Chem. 149, 437.

Sourkes, T. L., Lloyd, K. \& Birnbaum, H. (1968). Can. F. Biochem. 46, 267.

Suttle, N. F. \& Field, A. C. (1968). F. comp. Path. 78, 363.

Underwood, E. J. (r97r). Trace Elements in Human and Animal Nutrition 3rd ed. New York: Academic Press.

Young, D. S. \& Hicks, J. M. (1965). F. clin. Path. 18, 98. 